\title{
Progressive Supranuclear Palsy 1979: an overview
}

\author{
Brusa A., Mancardi G.L., Bugiani 0. \\ Clinica Neurologica dell'Università and Ospedale Galliera, Genova
}

Since the articles of Olszewski et al [125], Richardson et al [142], and Steele et al [168] in 1963 and 1964, so many papers have been devoted to Progressive Supranuclear Palsy (PSP) that it would be interesting to know whether diagnostic standards have changed, and, if so, how. Patients of Steele et al [168] early presented with voluntary gaze defect mainly downward, rigid neck extension, and stiff face. Dysarthria and a more diffuse rigidity developed in the advanced course, while a mild mental deterioration was present from the very beginning. In 1975, Steele [167] was able to outline a more comprehensive picture of PSP (Table I) on the basis of 72 cases collected from the literature, and stated that ophthalmoplegia and nuchal rigidity could be considered as most distinctive features of the syndrome. Furthermore, from that review it became apparent that signs of supranuclear palsy slowly progressed into signs of nuclear palsy. The present review was based upon 75 cases with neuropathological examination (Table II) and 310 clinical cases (Table III) published during the last 17 years (1963-1979), and upon two cases prior to 1963 [25, 34]. Controversial cases $[36,156]$ and PSP-like conditions $[22,27,116,145]$ were excluded. The analysis of data allows the whole problem of PSP to be placed into proper perspective.

1. In anatomical case series, mean age at onset was 57 years (range 47-74) and dęath occurred at 65 (51-81) (Fig. 1), after a course duration of $5.8(1-15)$ (Fig. 2). Males were affected more than females $(2.5: 1)$.

2. Symptoms at onset or within the first year were: unsteady gait with abrupt unexplained falls $(68.9 \%$ of anatomical cases) and postural abnormalities in upright stance $(50 \%)$, blurred vision $(63.6 \%)$, mental deterioration including personality changes $(52 \%)$, and dysarthria and/or dysphagia (40\%) (Table IV, Fig. 3).

TABLE I - Clinical findings in 72 cases of PSP (Steele [167])

Sex ratio (M/F): 2.4:1.

Mean age at onset: 55 years (range 45-73).

Mean duration: 5.6 years (range 2-11).

Early complaints: Unsteady gait, abrupt falls, slowness, forgetfulness, blurred vision, altered speech, irascibility and other changes in personality.

Symptoms: Slowness and limitations of voluntary movements of the eyes in the vertical plane, especially upward, with normal reflex movements. Difficulty in shifting gaze. Absence of near reflex and progressive ocular immobility with subsequent staring gaze and astonished expression. Stiff face. Dysarthria. Dysphagia. Explosive coughing. Extended neck. Rigidity of the limbs and bradykinesia. Awkwardness and hesitancy of gait.

Evolution: Severe or complete ophthalmoplegia with involvement of reflex ocular movements. Severe bradykjnesia. Rigid double hemiplegic posture with axial extension and brisk deep tendon reflexes.

Final: Akinetic state. 


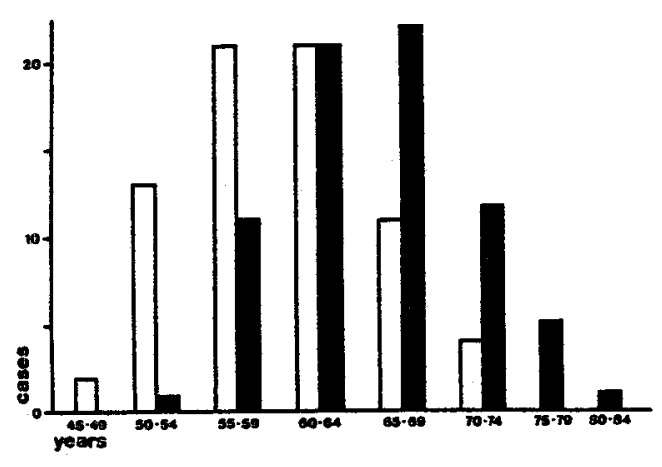

Fig. 1. Frequency distribution of age at onset (white bars) and at death (black bars) of 72 and 73 patients, respectively, with histologically ascertained PSP.

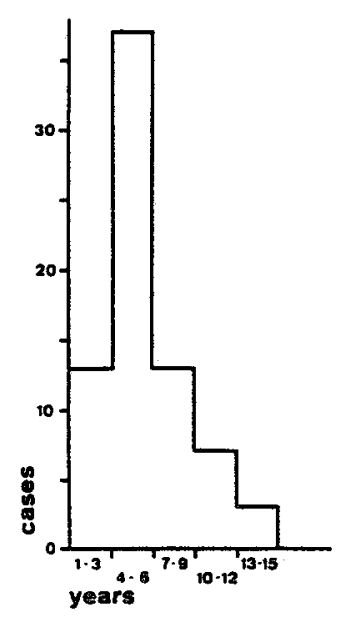

Fig. 2. Mean duration of the disease in 72 patients with histologically ascertained PSP.

TABLE II - Cases of PSP with histological examination of the CNS*

\begin{tabular}{|c|c|c|c|c|}
\hline & Author and reference & $\begin{array}{l}\text { Number } \\
\text { of cases }\end{array}$ & $\begin{array}{l}\text { Special field of } \\
\text { investigation * * }\end{array}$ & $\begin{array}{l}\text { Cases reported } \\
\text { previously }\end{array}$ \\
\hline 1963 & $\begin{array}{l}\text { Olszewski et al [125] } \\
\text { Richardson et al [142] }\end{array}$ & $\begin{array}{l}6 \\
6\end{array}$ & $\begin{array}{lll}a & b & g \\
a & b & g\end{array}$ & $\begin{array}{l}\text { Olszewski et al [125], } \\
\text { six cases }\end{array}$ \\
\hline 1964 & Steele et al [168] & 7 & $a b g$ & $\begin{array}{l}\text { Olszewski et al [125], } \\
\text { Richardson et al [142], } \\
\text { six cases }\end{array}$ \\
\hline 1967 & $\begin{array}{l}\text { Brusa et al [26] } \\
\text { Weinmann [194] }\end{array}$ & $\begin{array}{l}1 \\
1\end{array}$ & $\begin{array}{lll}a & b & g \\
a & b\end{array}$ & \\
\hline 1968 & David et al [48] & 2 & $a b$ & \\
\hline 1969 & $\begin{array}{l}\text { Anzil [12] } \\
\text { Behrman et al [20] } \\
\text { Blumenthal and Miller [23] } \\
\text { Cambier et al [30] } \\
\text { Rizzuto and Vio [144] }\end{array}$ & $\begin{array}{l}1 \\
4 \\
1 \\
1 \\
1\end{array}$ & $\begin{array}{lll}a & b & g \\
a & b & g \\
a & b & g \\
a & b & g \\
a & b & g\end{array}$ & \\
\hline 1970 & Constantinidis et al [37] & 1 & $a b$ e $g$ & \\
\hline 1971 & $\begin{array}{l}\text { Dix et al [53] } \\
\text { Jellinger [78] }\end{array}$ & $\begin{array}{l}2 \\
2\end{array}$ & $\begin{array}{lll}a & b & e \\
a & b & g\end{array}$ & \\
\hline 1972 & $\begin{array}{l}\text { Antunes et al [11] } \\
\text { Mannen et al [100] } \\
\text { Pfaffenbach et al [127] } \\
\text { Rajput et al [138] } \\
\text { Steele [166] }\end{array}$ & $\begin{array}{l}3 \\
1 \\
2 \\
1 \\
4\end{array}$ & $\begin{array}{lll}a & b & f \\
a & b \\
a & \\
a & b & f \\
a & b\end{array}$ & $\begin{array}{l}\text { Steele et al [168], } \\
\text { two clinical cases }\end{array}$ \\
\hline
\end{tabular}


TABLE II - cont'd

\begin{tabular}{|c|c|c|c|c|}
\hline & Author and reference & $\begin{array}{l}\text { Number } \\
\text { of cases }\end{array}$ & $\begin{array}{l}\text { Special field of } \\
\text { investigation" * }\end{array}$ & $\begin{array}{l}\text { Cases reported } \\
\text { previously }\end{array}$ \\
\hline 1973 & $\begin{array}{l}\text { Tellez-Nagel } \\
\text { and Wisniewski [173] }\end{array}$ & 1 & $a b c$ & \\
\hline 1974 & $\begin{array}{l}\text { Ishino et al [71] } \\
\text { Kurihara et al [94] } \\
\text { Mano et al [101] } \\
\text { Morax et al [112] } \\
\text { Powell et al [133] } \\
\text { Rizzo [143] } \\
\text { Rouzaud et al [146] } \\
\text { Roy et al [148] }\end{array}$ & $\begin{array}{l}1 \\
1 \\
1 \\
1 \\
2 \\
1 \\
1 \\
1\end{array}$ & 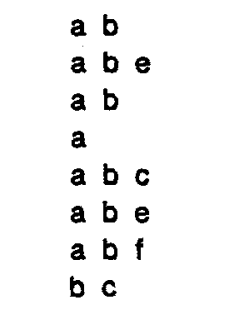 & \\
\hline 1975 & $\begin{array}{l}\text { Couet [41] } \\
\text { Durand [55] } \\
\text { Ishino et al [72] } \\
\text { Ishino and Otsuki [73] } \\
\text { Kobayashi et al [93] } \\
\text { Picard and Richardson jr. [128] } \\
\text { Probst and Dufresne [135] }\end{array}$ & $\begin{array}{l}1 \\
1 \\
2 \\
2 \\
1 \\
1 \\
1 \\
8\end{array}$ & $\begin{array}{l}a b d e f g \\
a b d e f g \\
a b \\
a b \\
a b g \\
a b c \\
a b\end{array}$ & $\begin{array}{l}\text { Cambier et al [30] } \\
\text { Rouzaud et al [146] } \\
\text { Ishino et al [71], one } \\
\text { case } \\
\text { Ishino et al [71, 72] } \\
\text { probably lijima et al } \\
\text { [69], as a clinical case }\end{array}$ \\
\hline 1976 & $\begin{array}{l}\text { Ishino and Otsuki [74] } \\
\text { Laurent [96] } \\
\text { Leygonie et al [98] }\end{array}$ & $\begin{array}{l}2 \\
3 \\
1\end{array}$ & $\begin{array}{l}a b \\
a b c d e f \\
a e\end{array}$ & $\begin{array}{l}\text { Ishino et al }[71,72] \text {, } \\
\text { Ishino and Otsuki }[73]\end{array}$ \\
\hline 1977 & $\begin{array}{l}\text { Daiziel and Griffiths [47] } \\
\text { Kissel et al [89] } \\
\text { Probst [134] } \\
\text { Tomonaga [176] }\end{array}$ & $\begin{array}{l}4 \\
1 \\
1 \\
1\end{array}$ & 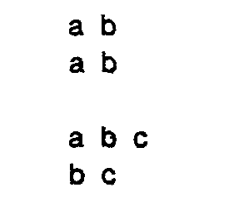 & $\begin{array}{l}\text { Kissel et al }[88] \\
\text { as a clinical case }\end{array}$ \\
\hline 1978 & $\begin{array}{l}\text { Agostini et al [1] } \\
\text { Nyberg-Hansen and Hoimsen } \\
\text { [123] } \\
\text { Schainker [152] }\end{array}$ & $\begin{array}{l}1 \\
1 \\
1\end{array}$ & $\begin{array}{l}a b d \\
a b e \\
a b\end{array}$ & \\
\hline 1979 & $\begin{array}{l}\text { Bugiani et al [28] } \\
\text { Ishii and Itoh [70] } \\
\text { Khunadorn et al [86] } \\
\text { Yagishita et al [196] }\end{array}$ & $\begin{array}{l}1 \\
1 \\
1\end{array}$ & $\begin{array}{lll}a & b & c \\
a & b \\
a & b & c\end{array}$ & $\begin{array}{l}\text { Brusa [25], } \\
\text { Brusa et al [26], } \\
\text { two cases }\end{array}$ \\
\hline
\end{tabular}

* Total is 22 more than the number of patients because there were several patients reported twice or more.

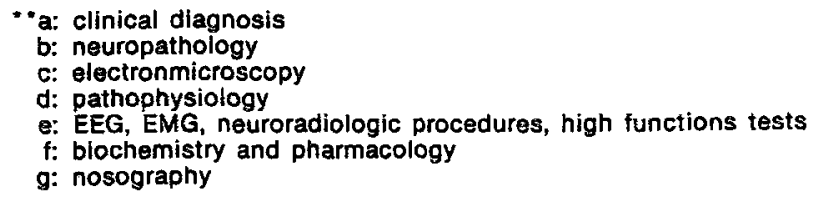


TABLE III - Cases of PSP without histological examination of the CNS*

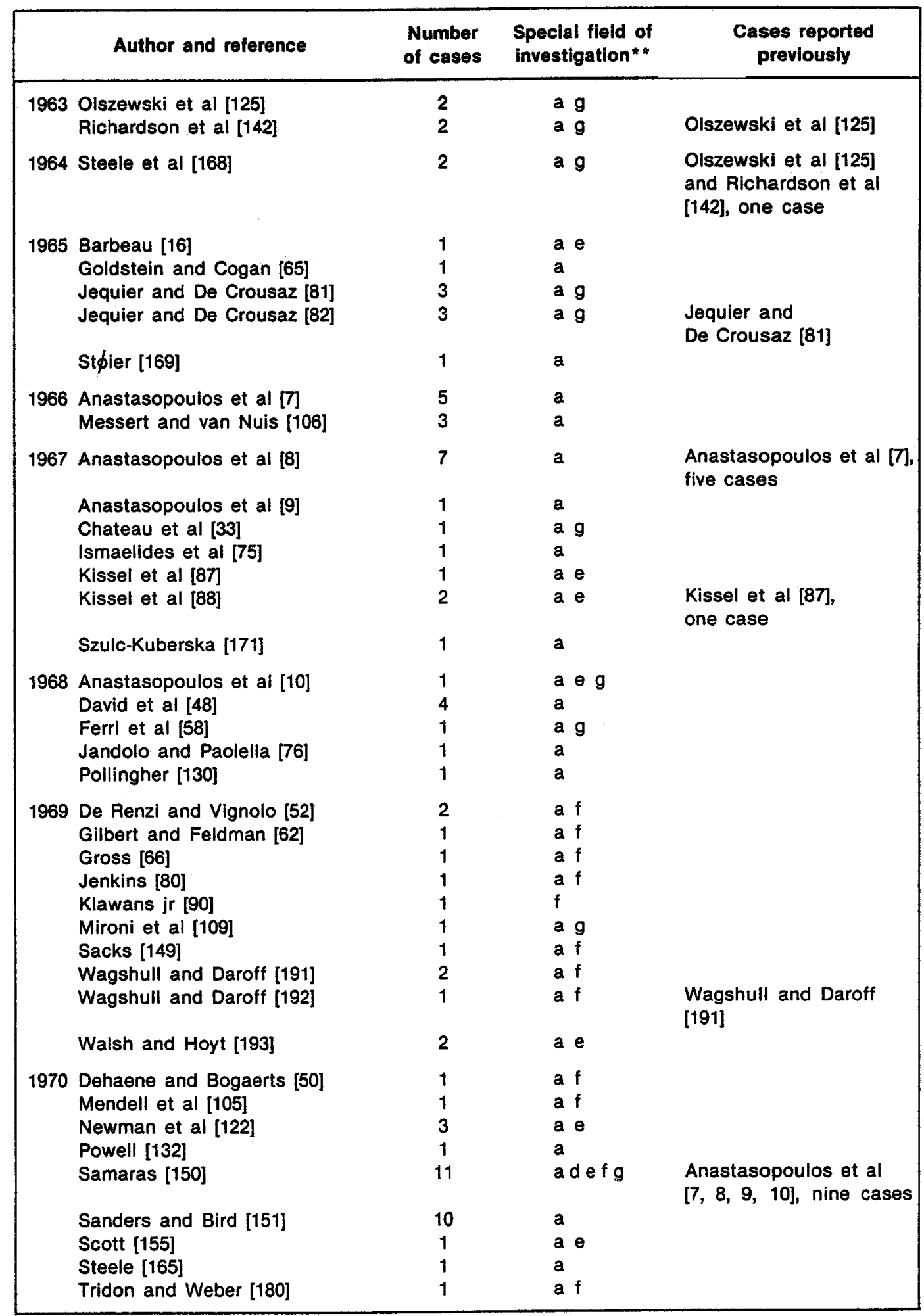


TABLE III - cont'd

\begin{tabular}{|c|c|c|c|c|}
\hline & Author and reference & $\begin{array}{l}\text { Number } \\
\text { of cases }\end{array}$ & $\begin{array}{l}\text { Special field of } \\
\text { investigation * * }\end{array}$ & $\begin{array}{l}\text { Cases reported } \\
\text { previousiy }\end{array}$ \\
\hline \multirow[t]{4}{*}{1971} & Dehaene and Bogaerts [51] & 1 & $a f$ & $\begin{array}{l}\text { Dehaene and } \\
\text { Bogaerts [50] }\end{array}$ \\
\hline & Dix et al [53] & 7 & a d e & \\
\hline & lijima et al $[69]$ & 3 & a e & \\
\hline & Klawans jr. and Ringel [92] & 3 & $a d f$ & $\begin{array}{l}\text { Klawans jr. [90], } \\
\text { one case }\end{array}$ \\
\hline \multirow[t]{11}{*}{1972} & Antunes et al [11] & 6 & $a f$ & \\
\hline & Balcells Riba et al [15] & 1 & a & \\
\hline & Corin et al [39] & 7 & a $\mathbf{g}$ & \\
\hline & Gimenez-Roldan & & & \\
\hline & and Esteban [63] & 1 & $a$ e f $g$ & \\
\hline & Mrozek et al [113] & 1 & a & \\
\hline & Mrozek et al [114] & 1 & a & Mrozek et al [113] \\
\hline & Nagamatsu et al [115] & 1 & a & \\
\hline & Pfaffenbach et al [127] & 42 & a & \\
\hline & Schott et al [154] & 2 & $d e f$ & \\
\hline & Simonetti and Ferrarini [158] & 1 & a d $g$ & \\
\hline \multirow{7}{*}{1973} & Alvarez [6] & 1 & a & \\
\hline & Curzon [45] & 2 & $f$ & \\
\hline & Donaldson [54] & 2 & $a f$ & \\
\hline & Klawans jr. [91] & 2 & $d f$ & \\
\hline & Mastaglia et al [102] & 11 & $a \in f$ & \\
\hline & Miquel et al [108] & 1 & a e & \\
\hline & Su and Goldensohn [170] & 12 & a e & $\begin{array}{l}\text { Antunes et al [11], } \\
\text { three anatomical cases, } \\
\text { six clinical cases }\end{array}$ \\
\hline \multirow{9}{*}{1974} & Albert et al [5] & 5 & $a \mathrm{e}$ & \\
\hline & Bentson and Keesey [21] & 6 & $a e$ & \\
\hline & Chase [32] & 3 & $\mathrm{~d} g$ & \\
\hline & Craus [42] & $?$ & adefg & \\
\hline & Liaño and Gimeno [99] & 1 & $a \mathrm{e}$ & \\
\hline & Morax et al [112] & 6 & a & \\
\hline & Singh et al [160] & 4 & $a f$ & \\
\hline & Spissu and Orzalesi [163] & 1 & a $f$ & \\
\hline & Trávnik [178] & 1 & a & \\
\hline \multirow{11}{*}{1975} & Arnott et al [13] & $t$ & $a e$ & \\
\hline & Arnott et al [14] & 1 & a e & Arnott et al [13] \\
\hline & Couet $[41]$ & 9 & adef $g$ & \\
\hline & Durand [55] & 1 & adef $g$ & \\
\hline & Kawamura et al [85] & 1 & $a e$ & \\
\hline & Mastaglia et at [103] & 4 & a & $\begin{array}{l}\text { Mastaglia et al [102], } \\
\text { three cases }\end{array}$ \\
\hline & Probst and Dufresne [135] & 6 & a & \\
\hline & Rouzaud et al [147] & 2 & a & $\begin{array}{l}\text { Rouzaud et al [146] } \\
\text { and Durand [55], one } \\
\text { anatomical case }\end{array}$ \\
\hline & Trevisan et al [179] & 2 & a e & \\
\hline & Varela and Ferrer [186] & 1 & a & \\
\hline & Velmurugendran et al [187] & 6 & $a$ & \\
\hline
\end{tabular}


TABLE $\mathrm{m}-$ cont'd

\begin{tabular}{|c|c|c|c|c|}
\hline & Author and reference & $\begin{array}{l}\text { Number } \\
\text { of cases }\end{array}$ & $\begin{array}{l}\text { Special field of } \\
\text { investigation * }\end{array}$ & $\begin{array}{c}\text { Cases reported } \\
\text { previously }\end{array}$ \\
\hline 1976 & $\begin{array}{l}\text { Kase et al (84) } \\
\text { Laurent }(96) \\
\text { Leygonie et al (98) } \\
\text { Singh et al (159) } \\
\text { Wada et al (190) }\end{array}$ & $\begin{array}{l}1 \\
7 \\
2 \\
3 \\
1\end{array}$ & $\begin{array}{l}a \text { e. } \\
a d e f \\
a e \\
a f \\
a \text { e g }\end{array}$ & \\
\hline 1977 & $\begin{array}{l}\text { Barontini and Pagnini (17) } \\
\text { Rafal et al (136) } \\
\text { Schleider and Nagurney (153) } \\
\text { Tashiro et al (172) } \\
\text { Troost and Daroff (181) } \\
\text { Umeda (182) }\end{array}$ & $\begin{array}{l}6 \\
6 \\
1 \\
2 \\
8 \\
1\end{array}$ & $\begin{array}{l}e \\
a f \\
a \\
a \text { e } f \\
e \\
a e\end{array}$ & \\
\hline 1978 & $\begin{array}{l}\text { Barontini et al (18) } \\
\text { Gross et al (67) } \\
\text { Hall (68) } \\
\text { Nyberg-Hansen } \\
\quad \text { and Holmsen (123) } \\
\text { Perkin et al (126) } \\
\text { Pinhas et at (129) } \\
\text { Umeda and Sakata (183) }\end{array}$ & $\begin{array}{l}1 \\
4 \\
1 \\
3 \\
5 \\
1 \\
1\end{array}$ & $\begin{array}{l}a e \\
e \\
a f \\
a e \\
a e f \\
a e \\
a e\end{array}$ & \\
\hline 1979 & $\begin{array}{l}\text { De Falco et al (49) } \\
\text { Gimenez-Roldan et al (64) } \\
\text { Jouvet and Perret (83) } \\
\text { Laffont et al (95) } \\
\text { Morariu (111) } \\
\text { Tolosa and Zeese (175) }\end{array}$ & $\begin{array}{l}5 \\
2 \\
8 \\
9 \\
3 \\
7\end{array}$ & $\begin{array}{l}f \\
a \text { e f } \\
e \\
a \text { e } \\
a \\
e\end{array}$ & \\
\hline
\end{tabular}

"Total is $\mathbf{3 5}$ more than the number of patients because there were several patients reported twice or more.

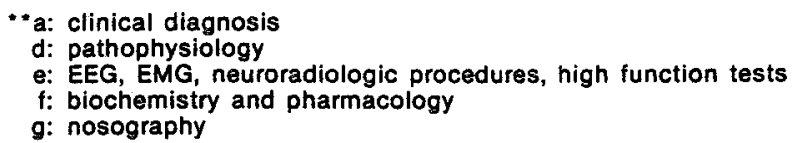

TABLE IV - Symptoms of PSP reported as appearing within the first year from the onset. Cases with neuropathological examination only

\begin{tabular}{|lcr|}
\hline Unsteady gait and abrupt falls & 40 out of 58 cases, $68.9 \%$ \\
Blurred vision & $14 / 22$ & $63.6 \%$ \\
Poor mentation & $26 / 50$ & $52.0 \%$ \\
Postural abnormalities in upright stance & $11 / 22$ & $50.0 \%$ \\
Dysarthria and/or dysphagia & $23 / 57$ & $40.3 \%$ \\
Stiff face & $15 / 51$ & $29.4 \%$ \\
Ptosis & $3 / 12$ & $25.0 \%$ \\
Diplopia & $1 / 4$ & $25.0 \%$ \\
Bradykinesia & $5 / 22$ & $22.7 \%$ \\
Axial rigidity & $10 / 52$ & $19.2 \%$ \\
Difficulty in vertical voluntary gaze & $9 / 58$ & $15.5 \%$ \\
Failure of vergence & $6 / 39$ & $15.3 \%$ \\
Monotonous, soft voice & $2 / 15$ & $13.3 \%$ \\
Staring gaze & $3 / 21$ & $14.2 \%$ \\
Difficulty in horizontal voluntary gaze & $2 / 36$ & $5.5 \%$ \\
\hline
\end{tabular}



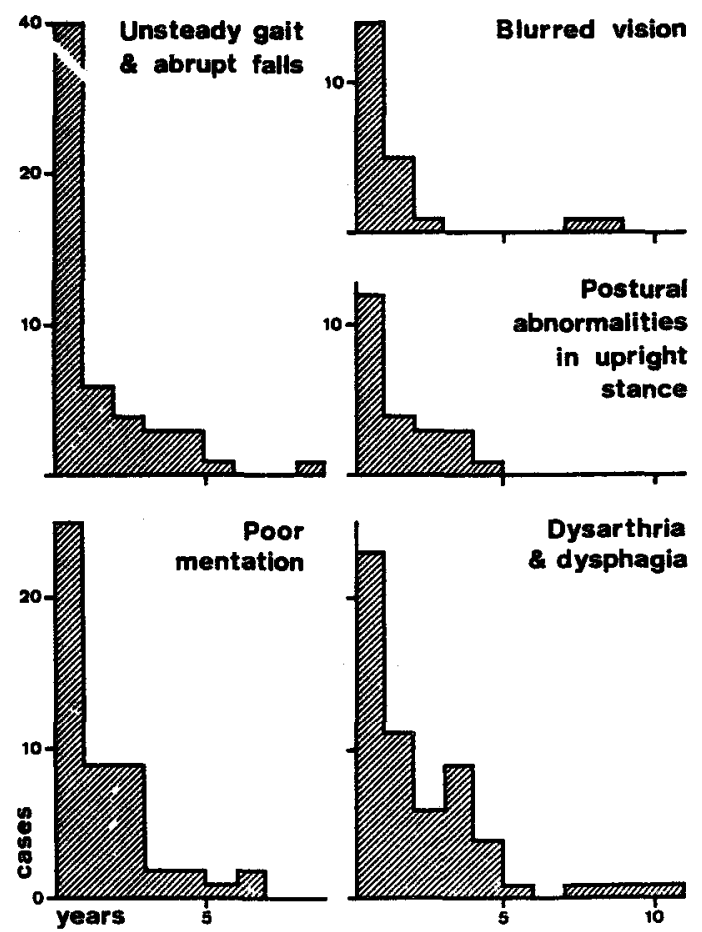

Fig. 3. Frequency distribution of the onset of some symptoms of PSP, in relation to the course of the disease.

3. The analysis of two such large case series confirmed that ophthalmoplegia was a clinical hallmark of PSP (Table V). Conjugate vertical voluntary movements proved to be affected more frequently than horizontal ones, while reflex movements were involved after ocular motility had been almost completely lost. In half of anatomical cases, slowness and limitation of both conjugate voluntary and vergence movements occurred $2-4$ years after the onset of any other symptom (Fig. 4). Furthermore, it was found that ophthalmoplegia, so relevant to the clinical diagnosis, may also develop late in the course of the disease. Neurophysiological procedures showed that the fast component of both optokinetic and vestibular nystagmus as well as any other ocular reflexes of retinal and vestibular origin, remained for a long time normal $[17,18,53$, $96,102,108,122,123,181,182,183]$. Impairment of reciprocal inhibition mechanisms during conjugate voluntary movement, due to degeneration of tectal, tegmental, and possibly cerebellar neurons, was thought to account for supranuclear ophthalmoplegia $[31,84,85,108$, 129]. These mechanisms were seldom corrected by oral L-dopa, amantadine, and methysergide $[49,63,64,68,102,105,114,136,137,158$, $160,163,172]$. Subsequent degeneration of oculomotor nuclei was commonly blamed for the progressive worsening of ocular motility, both voluntary and reflex $[23,48,63,71,78$, $100,130,135]$. As to lid motility, staring gaze was found to be due to ocular immobility and progressive widening of the ocular fissures as well. However, ptosis and blepharospasm were seldom observed. Although pupils were generally thought to remain intact, the light reflex was involved on some occasions, and the near reflex was said to be abolished $[18,26,86,96$, $127,158,160,163,171]$. As a detailed study of the pupillary response to accommodation was lacking, and accommodation was likely often confused with vergence $[39,41,48,53$, $63,92,96,109,132,138,151,165,166,168]$, trouble in the accommodation reflex may be partly responsible for the blurred vision so frequently camplained of.

4. Other signs of supranuclear palsy mainly involving the oropharyngeal and laryngeal muscles, together with hyperactive muscle stretch reflexes and Babinski sign (Table VI), occurred quite frequently even in the early course. Dysarthria and dysphagia commonly preceded the onset of ophthalmoplegia. Dysarthria was shown to be due to involvement of voluntary rather than reflex movements [13, $14,113]$. On examination, vocal rhythmic and musical repetition tests were executed with difficulty $(54,149)$.

5. In almost half of anatomical cases, the so called extrapyramidal signs such as axial rigidity, stiff face, bradykinesia, postural abnormalities both in upright stance and during walking (Table VII), developed within the two years of onset (Fig. 5).

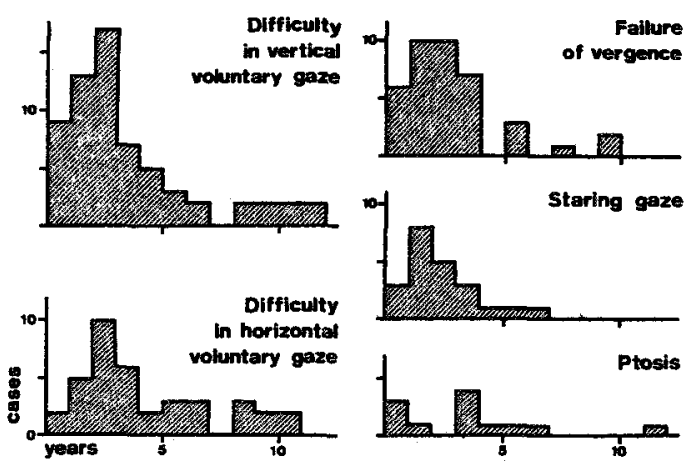

Fig. 4. Frequency distribution of the onset of some ocular symptoms, in relation to the course of the disease. 
TABLE $v$ - Absolute incidence of ocular signs in PSP as resulting from 74 cases with neuropathological examination, and 310 clinical cases

\begin{tabular}{|c|c|c|}
\hline & $\begin{array}{c}\text { Anatomical } \\
\text { cases }\end{array}$ & $\begin{array}{c}\text { Clinical } \\
\text { cases }\end{array}$ \\
\hline $\begin{array}{l}\text { Limitation, slowness of upward voluntary } \\
\text { movements, upward ophthalmoplegia }\end{array}$ & 68 & 242 \\
\hline $\begin{array}{l}\text { Limitation, slowness of downward voluntary } \\
\text { movements, downward ophthalmoplegia }\end{array}$ & 56 & 236 \\
\hline $\begin{array}{l}\text { Limitation, slowness of horizontal } \\
\text { voluntary movements, lateral gaze defect }\end{array}$ & 45 & 189 \\
\hline Failure of vergence & 44 & 139 \\
\hline $\begin{array}{l}\text { Staring gaze, marked stare, stare with } \\
\text { unfrequent blinking, retraction of the } \\
\text { eyelids, lid opening apraxia }\end{array}$ & 29 & 79 \\
\hline $\begin{array}{l}\text { Light reflex, present } \\
\text { absent }\end{array}$ & $\begin{array}{r}28 \\
1\end{array}$ & $\begin{array}{r}59 \\
2\end{array}$ \\
\hline $\begin{array}{r}\text { Doll's head reflex, present } \\
\text { absent }\end{array}$ & $\begin{array}{r}28 \\
5\end{array}$ & $\begin{array}{l}44 \\
22\end{array}$ \\
\hline $\begin{array}{r}\text { Pursuit movement, absent } \\
\text { present }\end{array}$ & $\begin{array}{r}20 \\
5\end{array}$ & $\begin{array}{r}106 \\
71\end{array}$ \\
\hline Ptosis & 11 & 12 \\
\hline Miosis, anisocoria & 10 & 14 \\
\hline Bell's phenomenon, absent & 8 & 40 \\
\hline Optokinetic nystagmus, abnormal or absent & 7 & 77 \\
\hline Spontaneous nystagmus & 7 & 24 \\
\hline Evoked nystagmus, abnormal or absent & 6 & 50 \\
\hline Blepharospasm & 4 & 29 \\
\hline Diplopia & 4 & 26 \\
\hline Saccadic movements, abnormal or absent & 2 & 40 \\
\hline Internuclear ophthalmoplegia & 2 & 6 \\
\hline Claude-Bernard-Horner syndrome & 1 & \\
\hline
\end{tabular}

In both case series, stiffness of neck and face was largely prevailing over rigidity of limbs and trunk. The neck was generally extended, but flexion and lateral rigidity were also noted. The results on these signs of oral anticholinergic drugs, L-dopa, and amantadine, were poor, while bromocryptine and methysergide were slightly effective in the early course [64, $136,137]$.

6. Despite the severity of dentate nucleus involvement, cerebellar signs were in no case prominent (Table VIII). Ataxia of the trunk was encountered more frequently than incoordination. In only one anatomical case could ataxia be related to altered deep sensation [123].
7. Personality changes and poor mentation were confirmed as hallmarks of PSP from onset (Table IX). Poor mentation was shown to be due to slow associative activity rather than memory and intellectual defects [5,37]. Transient improvement of mentation resulted from shunt procedures [111].

8. Among other miscellaneous signs (Table X), muscular wasting with denervation potentials, seizures, and sleep changes were encountered on some occasions. EEG changes were detected in the advanced course and during sleep as well $[41,83,95,96,98,154,170,178,179$, 195]. Evoked auditory brain stem responses were normal [175]. No satisfactory explanation of abrupt falls was ever given. 
TABLE VI - Absolute incidence of supranuclear signs other than ocular

\begin{tabular}{|lrr|}
\hline & $\begin{array}{c}\text { Anatomical } \\
\text { cases }\end{array}$ & $\begin{array}{c}\text { Clinical } \\
\text { cases }\end{array}$ \\
\hline Dysarthria & 66 & 150 \\
Hyperactive deep tendon reflexes, spasticity & 56 & 96 \\
Dysphagia & 55 & 82 \\
Babinski sign & 38 & 52 \\
Jaw-jerk & 22 & 42 \\
Explosive crying, exaggerated emotional responses & 17 & 35 \\
Glabellar reflex & 10 & 20 \\
Incontinence of urine & 9 & 14 \\
Difficulty with fine movements of the fingers & 8 & 19 \\
Grasp reflex & 7 & 9 \\
Snout reflex, orbicularis oris reflex & 6 & 36 \\
Palmomental reflex & 6 & 27 \\
Lingual movements slow, difficulty with rapid & & \\
tongue movements & 6 & 23 \\
Pharyngeal reflex, absent & 6 \\
Explosive loughing & 6 & 9 \\
Hoffmann sign & 5 & 14 \\
Winking-jaw phenomenon & 1 & 7 \\
\hline
\end{tabular}

Summing up, there is little doubt that middle-aged patients presenting with staring gaze, stiff and astonished face, impairment of conjugate voluntary eye movements and rigid neck extension could have escaped the diagnosis of PSP. A few years after onset the PSP syndrome is so stereotyped that cases prior to 1963, carefully described and presented as Parkinson's disease, postencephalitic parkinsonism, or so-called heterogeneous system degeneration, may well have been suffering from PSP (Table XI). On the contrary, early complaints such as unsteady gait, abrupt falls, blurred vision, dysarthria, dysphagia, slowness of movements, and axial rigidity, never suggested PSP until impairment of voluntary eye movements had appeared. The high diagnostic value assigned by clinicians to voluntary gaze defect was confirmed by the fact that this was the only sign concordantly found in both case series. After unquestionable gaze defect, no difficulty was encountered in differentiating PSP from Parkinson's disease [168], although several signs are probably common to both diseases $[38,46,110,157,161]$.

\section{Neuropathology and Nosography}

Most pathological papers alluded to PSP as a system degeneration of the nervous system. In fact, loss of nerve cells, simple and pigmentary atrophy, fiber tract demyelination, gliosis, and neurofibrillary tangles, involved a large portion of the integrating motor system including basal ganglia, tectum, nuclei and fiber tracts of the tegmental portions of the brain stem, substantia nigra, locus coeruleus, inferior olives, dentate nucleus, and rarely spinal cord. Progressive degeneration caused slight atrophy of the brain, in particular the brain stem, which in more advanced cases could be

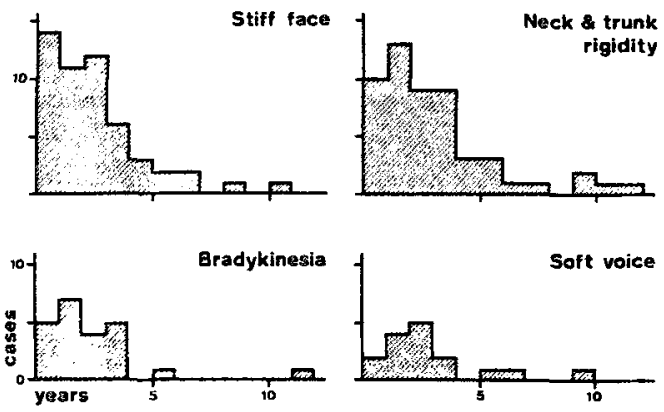

Fig. 5. Frequency distribution of the onset of some extrapyramidal symptoms, in relation to the course of the disease. 
TABLE Vn - Absolute incidence of extrapyramidal signs

\begin{tabular}{|c|c|c|}
\hline & $\begin{array}{l}\text { Anatomical } \\
\text { cases }\end{array}$ & $\begin{array}{l}\text { Clinical } \\
\text { cases }\end{array}$ \\
\hline Postural and gait troubles & 95 & 181 \\
\hline not defined & 42 & 72 \\
\hline retropulsion & 18 & 55 \\
\hline reduced arm swinging & 7 & 29 \\
\hline small steps & 5 & 22 \\
\hline propulsion, festination & 4 & 12 \\
\hline Rigidity, also dystonia, of the neck & 64 & 175 \\
\hline extensor & 30 & 56 \\
\hline not defined & 26 & 98 \\
\hline flexor & 6 & 9 \\
\hline lateral & 2 & 13 \\
\hline absent & & 2 \\
\hline $\begin{array}{l}\text { Spasticity, also stiffness, of the face, } \\
\text { amimia, facial spasm, peripheral facial }\end{array}$ & & \\
\hline palsy, trismus & 62 & 130 \\
\hline Bradykinesia & 37 & 99 \\
\hline $\begin{array}{l}\text { Rigidity of the limbs, gegenhalten } \\
\text { absent }\end{array}$ & $\begin{array}{r}35 \\
2\end{array}$ & $\begin{array}{r}41 \\
4\end{array}$ \\
\hline Rigidity of the trunk, axial dystonia & 34 & 67 \\
\hline Monotonous, soft voice, nasal speech & 21 & 73 \\
\hline $\begin{array}{l}\text { Parkinsonian tremor } \\
\text { absent }\end{array}$ & $\begin{array}{l}12 \\
14\end{array}$ & $\begin{array}{l}41 \\
29\end{array}$ \\
\hline $\begin{array}{l}\text { Cog-wheel } \\
\text { absent }\end{array}$ & $\begin{array}{r}12 \\
3\end{array}$ & $\begin{array}{r}35 \\
8\end{array}$ \\
\hline Palilalia & 5 & 20 \\
\hline Motor perseveration & 5 & 8 \\
\hline Altered handwriting, micrographia & 4 & 15 \\
\hline Salivation & 3 & 9 \\
\hline Acathisia & 2 & 1 \\
\hline
\end{tabular}

TABLE VII - Absolute incidence of cerebellar signs

\begin{tabular}{|lcc|}
\hline & $\begin{array}{c}\text { Anatomical } \\
\text { cases }\end{array}$ & $\begin{array}{c}\text { Clinical } \\
\text { cases }\end{array}$ \\
\hline Ataxia & 13 & 7 \\
absent & 12 & 2 \\
Dysmetria & 10 & 16 \\
absent & 11 & 13 \\
Romberg sign & 6 & 8 \\
absent & 2 & 2 \\
Adiadokokinesis & 4 & 11 \\
absent & 1 & \\
Tremor & 1 & 9 \\
\hline
\end{tabular}

detected during life by means of gas-encephalography and computer assisted tomography [21, $99,126,143,172]$. A gross clinico-pathologic correlation could also be traced between supranuclear signs and involvement of tegmental structures, nuclear signs and lesions of motor nerve nuclei, extrapyramidal signs and involvement of substantia nigra and striatum $[20,30$, $38,39,42,53,55,96,106,146,168]$. High levels of HVA in cerebrospinal fluid were thought to account for severity of nigral lesions $[11,32,45,91,92,96,140]$. Given the widespread distribution of lesions in the nervous system and some clinical similarities also, it has been speculated that PSP may belong to a group of non-familial, degenerative 
TABLE IX - Absolute incidence of mental symptoms

\begin{tabular}{|lcr|}
\hline & $\begin{array}{c}\text { Anatomical } \\
\text { cases }\end{array}$ & $\begin{array}{c}\text { Clinical } \\
\text { cases }\end{array}$ \\
\hline $\begin{array}{l}\text { Poor mentation } \\
\text { absent }\end{array}$ & 52 & 143 \\
Psychotic symptoms & 3 & 45 \\
Depression & 6 & 5 \\
Apathy & 3 & 10 \\
\hline
\end{tabular}

diseases including olivopontocerebellar atrophy, Parkinson's disease, striatonigral degeneration, and some related conditions $[4,24,38,39,43$, $61,79,97,117,121,124,139,141,164,174$, $177,184,185]$, and that there may be a phenotypical continuity from olivopontocerebellar atrophy through Parkinson's disease and PSP to striatonigral degeneration [56, 57, 107, 144]. The nosography of PSP has been also based upon neurofibrillary tangles involving subcortical structures, so a non-systemic subcortical argyrophilic dystrophy including PSP as well as any other condition with tangles except Alzheimer's disease, has been postulated 178 . 156]. When PSP tangles were shown to consist of straight filaments approximately $15 \mathrm{n} \mu$ wide $[28,96,128,133,148,173]$, it became possible to keep PSP separate from any other disease with cortical and/or subcortical neurofibrillary changes, such as presenile and senile dementia, postencephalitic parkinsonism, parkinsonismdementia complex of Guam, and Down syndrome, in which tangles consisted of paired helical filaments $22 \mathrm{n} \mu$ wide. Paired helical filaments were found on some occasions in
TABLE X - Miscellaneous signs

\begin{tabular}{|lrr|}
\hline & $\begin{array}{c}\text { Anatomical } \\
\text { cases }\end{array}$ & $\begin{array}{c}\text { Clinical } \\
\text { cases }\end{array}$ \\
\hline Abrupt falls & 47 & 107 \\
Blurred vision & 24 & 87 \\
Lethargy & 9 & 2 \\
Muscle wasting & 7 & 8 \\
Selzures & 7 & 1 \\
Insomnia & 6 & 7 \\
Apraxia & 4 & 4 \\
Athetosis, chorea, & & \\
$\quad$ ballismus & 4 & 1 \\
Fasciculations & 3 & 4 \\
Aphasia & 3 & 2 \\
Righting reactions, & & \\
$\quad$ abnormal & 2 & 18 \\
Dizzines & 1 & 7 \\
Deep sensation, & & \\
$\quad$ abnormal & 1 & 4 \\
Respiratory control & & \\
$\quad$ failure & & \\
Echolalia & & \\
Photophobia & & \\
\hline
\end{tabular}

PSP $[70,134,176,196]$, but the question was unanswered whether they originated from straight filaments or were related to concomitant nerve cell aging. A possible relationship of PSP to transmissible dementias was suggested by spongiform encephalopathy which developed in primates inoculated with a brain suspension of a patient affected by PSP [104].

Addendum. New papers on PSP appeared in 1979 after this editorial had been submitted: CHU F.C., Reingold D.B., Cogan D.G., Wirilams A.C: The eye movement disorders of progressive supranuclear palsy. Ophthalmol. (Rochester), 86: 422-428, 1979.

Insausti T., Ferreiro J.L., Bertotri A.C., Pugliese M.I.: Enfermedad de Steele-RichardsonOlszewski. Prensa Med. Argent., 66: 157-161, 1979.

Acknowledgments: This investigation was financially supported by Consiglio Nazionale delle Ricerche (78.02012.04), and Regione Liguria.

Address reprint requests to: Dr. A. Brusa

Ospedale Galliera

16128 Genova (Italia) 
TABLE XI - Cases of PSP prior to 1963

\begin{tabular}{|c|c|c|c|c|c|c|c|}
\hline & Year and Author & $\begin{array}{l}\text { Number } \\
\text { of } \\
\text { cases }\end{array}$ & $\begin{array}{l}\text { Clinical } \\
\text { diagnosis } \\
\text { original }\end{array}$ & $\begin{array}{l}\text { Source of } \\
\text { the new } \\
\text { classiffication }\end{array}$ & $\begin{array}{l}\text { Neuropath- } \\
\text { ological } \\
\text { examination }\end{array}$ & $\begin{array}{l}\text { Sub. } \\
\text { cortical } \\
\text { tangles }\end{array}$ & $\begin{array}{l}\text { Straight } \\
\text { fllaments } \\
\text { at EM }\end{array}$ \\
\hline 1904 & Posey [131], & & & & & & \\
\hline 1905 & Spiller [162], and & & & & & & \\
\hline 1927 & Cadwalader [29] & 1 & $\begin{array}{l}\text { Postencephalitic } \\
\text { parkinsonism }\end{array}$ & $\begin{array}{l}\text { Behrman } \\
\text { et al [20] }\end{array}$ & & & \\
\hline 1909 & Janischewsky $[7]$ & 1 & $\begin{array}{l}\text { Parkinson's } \\
\text { disease }\end{array}$ & Steele [166] & & & \\
\hline 1926 & Alajouanine et al [2]- & 1 & $\begin{array}{l}\text { Extrapyramidal } \\
\text { pseudobulbar } \\
\text { syndrome }\end{array}$ & $\begin{array}{l}\text { Behrman } \\
\text { et al [20] }\end{array}$ & & & \\
\hline 1927 & Crouzon et al [44] & 1 & $\begin{array}{l}\text { Extrapyramidal } \\
\text { syndrome }\end{array}$ & $\begin{array}{l}\text { Constantinidis } \\
\text { et al [37] }\end{array}$ & & & \\
\hline 1928 & Alajouanine et al [3] & 1 & $\begin{array}{l}\text { Extrapyramidal } \\
\text { pseudobulbar } \\
\text { syndrome }\end{array}$ & $\begin{array}{l}\text { Constantinidis } \\
\text { et al }[37]\end{array}$ & & & \\
\hline 1929 & Cornil and Kissel [40] & 1 & $\begin{array}{l}\text { Extrapyramidal } \\
\text { syndrome }\end{array}$ & $\begin{array}{l}\text { Behrman } \\
\text { et al }[20]\end{array}$ & & & \\
\hline 1932 & $\begin{array}{l}\text { Français and } \\
\text { Vernotte }[60]\end{array}$ & 1 & $\begin{array}{l}\text { Extrapyramidal } \\
\text { syndrome }\end{array}$ & & & & \\
\hline 1936 & Ford and Waish [59] & 1 & & $\begin{array}{l}\text { Behrman } \\
\text { et al [20] }\end{array}$ & yes & & \\
\hline 1940 & Verhaart $\{188\}$ & 1 & $\begin{array}{l}\text { Unclassified } \\
\text { degenerative } \\
\text { disease }\end{array}$ & & yes & & \\
\hline 1951 & Chavany et al [34] & 1 & $\begin{array}{l}\text { Postencephalitic } \\
\text { parkinsonism }\end{array}$ & $\begin{array}{l}\text { Steele et al } \\
{[168]}\end{array}$ & yes & yes & \\
\hline 1958 & Verhaart [189] & 1 & $\begin{array}{l}\text { Heterogenous } \\
\text { systemic } \\
\text { degeneration }\end{array}$ & $\begin{array}{l}\text { Steele et al } \\
\text { [168] }\end{array}$ & yes & & \\
\hline 1961 & $\begin{array}{l}\text { Neumann }[118, \\
119,120]\end{array}$ & 1 & $\begin{array}{l}\text { Heterogenous } \\
\text { system } \\
\text { degeneration }\end{array}$ & $\begin{array}{l}\text { Steele et al } \\
{[168]}\end{array}$ & yes & yes & \\
\hline 1961 & Brusa [25] & 1 & $\begin{array}{l}\text { Multisystem } \\
\text { degeneration }\end{array}$ & $\begin{array}{l}\text { Steele et al } \\
{[168]}\end{array}$ & yes & $\begin{array}{c}\text { yes, } \\
\text { Steele } \\
\text { et al [168] }\end{array}$ & $\begin{array}{c}\text { yes, } \\
\text { Bugiani } \\
\text { et al [28] }\end{array}$ \\
\hline 1963 & $\begin{array}{l}\text { Barraquer. } \\
\text { Bordás [19] }\end{array}$ & 1 & $\begin{array}{l}\text { Pseudobulbar } \\
\text { syndrome }\end{array}$ & $\begin{array}{l}\text { Giménez- } \\
\text { Roldàn and } \\
\text { Esteban [63] }\end{array}$ & & & \\
\hline
\end{tabular}

\section{References}

[1] Agostini L., Bernardi G., Giacomini P.: Contributo anatomo-clinico alla conoscenza della sindrome presenile di Steele-RichardsonOlszewski (Descrizione di un caso). Riv. Neurol., 48, 271-283, 1978.

[2] Alajouanine Th., Delafontaine P., Lacan J.: Fixité du regard par hypertonie, prédominant dans le sens vertical, avec conservation des mouvements automatico-réflexes, aspect spécial de syndrome de Parinaud par hypertonie associée d̀ un syndrome extrapyramidal avec troubles pseudobulbaires. Rev. Neurol. (Paris), 2, 410-418, 1926 .
[3] Alajouanine Th., Schiff P., Schiff S., Montassut M.: Dysgraphie hypertonique et syndrome de Parinaud chez un pseudo-bulbaire extrapyramidal. Rev. Neurol. (Paris), 1 , $112-116,1928$.

[4] Alajouanine Th., Thurel R.: Révision des paralysies des mouvements associés des globes oculaires (Contribution à l'étude de la dissociation des activités volontaire et réflexe) (Premier mémoire). Rev. Neurol. (Paris), 1, 125-169, 1931.

[5] Albert M.L., Feldman R.G., Whlis A.L.: The 'subcortical dementia' of progressive supranuclear palsy. J. Neurol. Neurosurg. Psychiatry, 37, 121-130, 1974. 
[6] Alvarez U.G.: Parálisis supranuclear progresiva. Riv. Méd. Chile, 101, 718-719, 1973.

[7] Anastasopoulos G., Routsonis C.G., Constas C.G.: Dystonie oculo-facio-cervicale. Proc. 5th Cong. Greek-Yugoslav O.N.O. Soc., Salonica 1966 , pp. $69-72$.

[8] Anastasopoulos G., Routsonis C., Constas C.G.: Dystonie oculo-facio-cervicale (progressive supranuclear palsy). Rev. Neurol. (Paris), 116, 85-88, 1967.

[9] Anastasopoulos -G.K., Konstas K.G., Siamoulis K.: Cerebral progressive supranuclear palsy. A case report. Neuropsychiatrika Chronika, 6, 64-67, 1967. (In Greek).

[10] anastasopoutos G., Routsonis K., CocchinI D., Konstas G.: Oculo-facio-cervical dystonia. (Progressive Supranuclear palsy). Proc. 4th Panhellenic Cong. Greek Neurologists and Psychiatrists, Salonica 1968, pp. 205-208. (In Greek).

[11] ANTUNES J.L., YAHR M.D., DUvoisin R.C.: Progressive supranuclear palsy: A clinical, pathological, and biochemical study. Neurology (Minneap.), 22, 445, 1972.

[12] ANzil A.P.: Progressive supranuclear palsy. Case report with pathological findings. Acta Neuropathol. (Berl.), 14, 72-76, 1969.

[13] ARnott G., Lothe-Munier E., Vanecloo F.M., MiLBLed G.: Analyse sonagraphique de la dysarthrie d'un syndrome de Steele-OlszewskiRichardson. Lille Méd., 20, 607-616, 1975.

[14] ARnotT G., Lothe-Munier E., Vanecloo F., MiLBLED G.: Sonagraphic and auditory analysis of dysarthria in a case of Steele-OlszewskiRichardson syndrome. Folia Phoniat., 27, 443-456, 1975.

[15] Balcells Riba M., Jubert Gruart J., EspaDALER MEDINA J.M.: Parálisis supranuclear progresiva $o$ distonia oculo-facio-cervical. Estúdio de un caso clínico. XXIV Reunión Anual Soc. Esp. Neurol., Barcelona 1972.

[16] Barbeau A.: Dégénérescence plurisystematisée du névraxe. Syndrome de Steele-RichardsonOlszewski. Union Méd. Can., 94, 715-718, 1965.

[17] Barontini F., Pagnini P.: Paralisi sopranucleare progressiva $(m$. di Steele, Richardson, Olszewski). Importanza dei reperti otoneurologici nella diagnosi e nella fisiopatologia della malattia. Nuovo Arch. Ital. Otol., 5, 827-836, 1977.

[18] Barontini F., Cappelli L., Marconi G.: Paralisi sopranucleare progressiva: descrizione di un caso ad insorgenza precoce associato ad atrofie muscolari. Riv. Pat. Nerv. Ment., 90, 195-206, 1978.

[19] Barraquer Bordás L.: Afectación de los movimientos oculares de verticalidad en el curso de procesos desintegrativos de origen vascular. Rev. Esp. Otoneurooftalmol. Neurocir., 22, 31-35, 1963.

[20] Behrman S., Carroll J.D., Janota I., MATTHEWs W.B.: Progressive supranuclear palsy: Clinico-pathological study of four cases. Brain, 92, 663-678, 1969.

[21] Bentson J.R., Keesey J.C.: Pneumoencephalography of progressive supranuclear palsy. Radiology, 113, 89-94, 1974.
[22] Biglan A.W., Ellis F.D., Wade Th. A.: Supranuclear oculomotor palsy and exotropia after tetanus. Am. J. Ophthalmol., 86, 666-668, 1978.

[23] Blumenthal H., Miller C.: Motor nuclear involvement in progressive supranuclear palsy. Arch. Neurol., 20, 362-367, 1969.

[24] BoRIT A., RUBinstein L.J., URICH H.: The striatonigral degenerations. Putaminal pigments and nosology. Brain, 98, 101-112, 1975.

[25] BRusA A.: Dégénérescence plurisystématisée du névraxe, de caractère sporadique, à début tardif et évolution subaiguë. Etude anatomo-clinique d'un cas difficile à classer. Rev. Neurol. (Paris), $104,412-429,1961$.

[26] Brusa A., Bugiani O., Priori A.: Les dégénérescences plurisystématisées du névraxe: nouvelle contribution anatomo-clinique. Sem. Hôp. Paris, 43, 1574-1580, 1967.

[27] Bugiani O., AGNOLI A.: Sur une polioencéphalopathie progressive avec dégénérescences neurofibrillaires. Acta Neuropathol. (Berl.), 15, 279-283, 1970.

[28] Bugiani O., Mancardi G.L., Brusa A., EDERLI A.: The fine structure of subcortical neurofibrillary tangles in progressive supranuclear paisy. Acta Neuropathol. (Berl.), 45, 147-152, 1979.

[29] Cadwalader W.B., 1927: quoted by Collier J. [35].

[30] Cambier J., Escourolle R., Masson M. LeCheVAlier B.: La paralysie supra-nucléaire progressive. A propos d'une observation anatomo-clinique. Rev. Neurol. (Paris), 121, 139-154, 1969.

[31] Cambier J., Masson M., Lechevalier B.: Etude anatomo-clinique des mouvements conjugués des yeux. Rev. Otoneuroophtalmol., 44, 25-42, 1972.

[32] Chase Th. N.: Serotonergic mechanisms and extrapyramidal function in man. Adv. Neurol., 5, 31-39, 1974.

[33] Chateau R., Groslambert R., Perret J.: Dystonie oculo-facio-cervicale. A propos d'une observation. Lyon Méd., 218, 1425-1434, 1967.

[34] Chavany J.A., Van Bogaert L., GodlevskI S.: Sur un syndrome de rigidité à prédominance axiale, avec perturbation des automatismes oculo-palpébraux d'origine encéphalitique. Presse Méd., 59, 958-962, 1951.

[35] Collier J.: Nuclear ophthalmoplegia, with especial reference to retraction of the lids and ptosis and to lesions of the posterior commissure. Brain, 50, 488-498, 1927.

[36] Colmant H.J.: Progressive supranuclear palsy. Arch. Psychiat. Nervenkr., 214, 324-330, 1971.

[37] Constantinidis J., Tissot R., dE AJURIaGUERRA J.: Dystonie oculo-facio-cervicale ou paralysie progressive supranucléaire de Steele. Richardson-Olszewski. Pseudo-paralysie du regard, troubles visuo-spatiaux, pseudo-démence, altérations neuronales. Rev. Neurol. (Paris), 122, 249-262, 1970.

[38] CORIN M.S., Elizan T.S., BENDER M.B.: Oculomotor function in patients with Parkinson's disease. J. Neurol. Sci., 15, 251-265, 1972. 
[39] Corin M.S., Mones R.J., Elizan T.S., Bender M.B.: Paresis of vertical gaze in basal ganglia disease. Mt. Sinai J. Med., 39, 330-342, 1972.

[40] Cornil L., Kissel P.: Syndrome extrapyramidal avec paralysie verticale du regard et conservation des mouvements automatico-réflexes. Remarques sur les synergies oculo-palpébrales du syndrome de Parinaud. Rev. Neurol. (Paris), 1, 1189-1191, 1929.

[41] Cover P.: Dix observations de paralysie supra-nucléaire progressive de Steele-Richardson-Olszewski. Thèse, Paris, 1975.

[42] CRAUS A.: La paralysie supranucléaire progres. sive (syndrome de Steele-Richardson-Olszewski). Revue générale à propos de 72 observations de la littérature dont 27 anatomo-cliniques. Thèse, Nancy, 1974.

[43] CRITChLeY M.: Arteriosclerotic parkinsonism. Brain, 52, 23-83, 1929.

[44] Crouzon M.O., Alajouanine Th., De Seze S. Sur un syndrome d'hypertonie généralisée avec troubles pseudo-bulbaires. Rev. Neurol. (Paris) 2, 672-678, 1927

[45] CuRzon G.: Involuntary movements other than parkinsonism: Biochemical aspects. Proc. R. Soc. Med., 66, 873-876, 1973.

[46] DALzaE J.A.: Don't confuse it with Parkinson's. Progressive supranuclear palsy (PSNP) resembles Parkinson's and dementia. Poor response to therapy may be the first clue. Mod. Geriatrics, 7, 60-61, 1977.

[47] DALZIEL J.A., GRIFrTHS R.A.: Progressive supranuclear palsy. Age Ageing, 6, 185-191, 1977.

[48] David N.J., Mackey E.A., SMrth J.L.: Further observations in progressive supranuclear palsy. Neurology (Minneap.), 18, 349-356, 1968.

[49] De Falco F.A., Barbieri F., Mansi D., Striano S., Orsini A., Campanella G.: La metisergide nel trattamento della paralisi sopranucleare progressiva. Atti XXI Cong. Soc. Ital. Neurol., Catania, 1979, p. 242.

[50] Dehaene I., Bogaerts M.: L-Dopa in progressive supranuclear palsy. Lancet, ii, 470, 1970.

[51] Dehaene I., Bogaerts M.: La paralysie supranucléaire progressive. $A$ propos d'un cas avec "apraxie de l'ouverture des yeux" et réaction favorable au traitement par L-Dopa. Acta Neurol. Belg., 71, 141-145, 1971.

[52] DE Renzi E., Vignolo L.A.: L-Dopa for progressive supranuclear palsy. Lancet, ii, 1360, 1969.

[53] DIX M.R., Harrison M.J.G., Lewis P.D.: Progressive supranuclear palsy the Steele. Richardson-Olszewski syndrome). A report of 9 cases with particular reference to the mechanism of the oculomotor disorder. J. Neurol. Sci., 13, 237-256, 1971.

[54] Donatdson I.Mac G.: The treatment of progressive supranuclear palsy with L-Dopa. Aust. N.Z. J. Med., 3, 413-416, 1973.

[55] DURAND J.P.: La paralysie supranucléaire progressive (syndrome de Steele-RichardsonOlszewski). Thèse, Tours, 1975.

[56] Evrard E., Hariga J., Martin J.J., Reznik M.: Maladie de Hallervorden-Spatz tardive avec importante participation réticulaire et cérébell- euse. Psychiat. Neurol. Neurochir., 71, 243-254, 1968.

[57] FAHN S.: Secondary Parkinsonism, in E.S. GoldensoHn, S.H. APPEL, Scientific Approaches to Clinical Neurology. Philadelphia, Lea \& Febiger, 1977, pp. 1157-1189.

[58] Ferri E., Parma M., Passeri S., Zampollo A.: La sindrome di Steele, Richardson e Olszewski (o "progressive supranuclear palsy"). Minerva Med., 59, 5831-5838, 1968.

[59] FoRd F.R., Walsh F.B.: Clinical obsevations upon the importance of the vestibular reflexes in ocular movements. The effects of section of one or both vestibular nerves. Bull. Hopkins Hosp., 58, 80-88, 1936.

[60] Français H., Vernotte S.: Syndrome de Parinaud associé à un syndrome de rigidité extra-pyramidale. Rev. Otoneuroophtalmol., 10, 739-741, 1932.

[61] FreUnd C.S., RotTer R.: Ueber extrapyramidale Erkrankungen des höheren Alters mit einem Beiträg zur Pathogenese seniler Parenchym-veränderungen. Z. Gesamte Neurol. Psychiatr., 115, 198-271, 1928.

[62] GILBERT J.J., FELDMAN R.G.: L-Dopa for progressive supranuclear palsy. Lancet, ii, 494, 1969.

[63] Gmenez-Roldan S., Esteban A.: Parálisis supranuclear progresiva. Revisión crítica, con una nota sobre los trastornos de la expresión verbal y acción de la $L$-dopa. Arch. Neurobiol. (Madr.), 35, 41-60, 1972.

[64] Gmenez-Roldan S., de ANdres C., Salinero E.: Terapéutica de la parálisis supranuclear progresiva. Efectos de la metisergida y bromocriptina sobre algunas funciones psiconeurológicas y motoras. Rev. Clin. Esp., 153, 21-27, 1979.

[65] Goldstenn J.E., Cogan D.G.: Apraxia of lid opening. Arch. Ophthalmol., 73, 155-159, 1965.

[66] Gross M.: L-Dopa for progressive supranuclear palsy. Lancet, ii, 1359-1360, 1969.

[67] Gross R.A., SPEHLMaNN R., Daniels J.C. Sleep disturbances in progressive supranuclear palsy. Electroencephal. Clin. Neurophysiol., 45, $16-25,1978$.

[68] HALI J.A.S.: Sindrome di Steele-RichardsonOlszewski: descrizione di un caso. Practitioner (ed. ital.), 1, 149-152, 1978.

[69] Iuma M., Harada M., Imano H., Shtikita K. Sajo M., Schmizu T., Kosugi T.,Hatano M., Oshuma K.: Progressive supranuclear palsy (Steele syndrome) three clinical cases. Diagnosis Ther., 59, 1827-1835, 1971. (In Japanese).

[70] IsHII N., Iтон K.: Progressive supranuclear palsy with twisted tubules in Alzheimer neurofibrillary tangles. Clin. Neurol. (Tokio), 19, 372-378, 1979. (Abstract in English).

[71] Ishino H., Higashi H., Kuroda S., YabuKi S., HayahaRa T., OtsukI S.: Motor nuclear involvement in progressive supranuclear palsy. J. Neurol. Sci., 22, 235-244, 1974.

[72] IsHINo H., IKEDA H., OTsUKI S.: Contribution to clinical pathology of progressive supranuclear palsy (Subcortical argyrophilic dystrophy). On the distribution of neurofibrillary tangles in the basal ganglia and brain-stem and its clinical 
significance, J. Neurol. Sci., 24, 471-481, 1975.

[73] IsHINo H., OTsuKI S.: Distribution of Alzheimer's neurofibrillary tangles in the basal ganglia and brain stem of progressive supranuclear palsy and Alzheimer's disease. Folia Psychiatr. Neurol. Jpn., 29, 179-187, 1975.

[74] Ishino H., Otsuki S.: Frequency of Alzheimer's neurofibrillary tangles in the cerebral cortex in progressive supranuclear palsy (Subcortical argyrophilic distrophy). J. Neurol. Sci., 28, 309-316, 1976.

[75] Ismaelides P., Partsafillides T., Kazis AR.: Progressive supranuclear palsy with tonic plantar reflex. Neuropsychiatrika Chronika, 6 . 245-248, 1967. (In Greek).

776] JaNDOLO B., PAOLELla P.: Contributo allo conoscenza delle paralisi sopranucleari bulboponto-mesencefaliche ad andamento cronico. Riv. Neurol., 38, 449-453, 1968.

[77] JANISCHEWSKY A.: Un cas de maladie de Parkinson avec syndrome pseudobulbaire et pseudo-ophtalmoplegique. Quelques considérations sur la pathogénie de cette maladie. Rev. Neurol. (Paris), 2, 823-831, 1909.

[78] Jellinger K.: Progressive supranuclear paisy (Subcortical argyrophilic dystrophy). Acta Neuropathol. (Berl.), 19, 347-352, 1971.

[79] Jellinger K., DANielczyK W.: Striato-nigrale Degeneration. Acta Neuropathol. (Berl.), 10, 242-257, 1968,

[80] JENKINS R.: L-Dopa for progressive supranu clear palsy. Lancet, ii, 742, 1969.

[81] JÉQUier M., DE CROUSAz G.: Dystonie oculofacio-cervicale (Progressive supranuclear palsy). Confin. Neurol., 25, 347-351, 1965.

[82] JÉQuier M., DE CRousAz G.: Dystonie oculofacio-cervicale (Progressive supranuclear palsy). Rev. Neurol. (Paris), 112, 406-409, 1965.

[83] Jouvet M., Perret J.L.: Valeur des examens polygraphiques de sommeil au cours de certaines affections "dégénératives" du tronc cérébral. Les neuromédiateurs du tronc cérébral. 2ème Réunion Int. Hôp. Neurol. (Lyon, 1979). Paris, Sandoz Éd., p. 25.

[84] Kase M., Warabi T., Tashiro K.: $A$ case of progressive supranuclear palsy: Electrophysiological analysis of the abnormal oculomotor function. Jpn. J. Ophthaimol., 20, 466-473, 1976.

[85] Kawamura Y., Shibasaki H., Shida K., Goto 1., Kurorwa Y.: Progressive supranuclear palsy with Korsakoff syndrome. Report of a case and study on the pathophysiology of the eye movement disturbance. Clin. Neurol. (Tokyo), 15, 535-540, 1975. (Abstract in English).

[86] KHUNADORN N., KalUMPaHETI R., SAIPETARA K.: Blepharospasm in progressive supranuclear palsy. The first case in Thailand. J. Med. Ass. Thai., 62, 89-92, 1979.

[87] Kissel P., Cordier J., Picaro L.: Dystonie oculo-facio-cervicale (Syndrome de Steele, Richardson et Olszewski). Rev. Otoneuroophtalmol., 39, 113-118, 1967.

[88] Kissel P., Schmitt J., Barrucand D., Picard L.: Un syndrome neurologique méconnu: la dystonie oculo-facio-cervicale (Syndrome de Steele, Richardson et Olszewski). Ann. Méd.
Nancy, 6, 556-573, 1967.

[89] Kissel P., Floquet J., ANDre J.M., Thomas CH., Craus A.: Syndrome de Steele, Richardson et Olszewski. Etude anatomo-pathologique d'un cas clinique rapporté en 1966. Rev. Otoneuroophtalmol., 49, 57-63, 1977.

[90] KLawans H.L. jr.: L-Dopa for progressive supranuclear palsy. Lancet, ii, 1359, 1969.

[91] KLaWaNs H.L. jr.: The pharmacology of extrapyramidal movement disorders. Monogr. Neurol. Sci., 2, 1973.

[92] Klawans H.L. jr., Ringel S.P.: Observations on the efficacy of L-Dopa in progressive supranuclear palsy. Eur. Neurol., 5, 115-129, 1971.

[93] Kobayashi M., Iuma M., Hatano M., Axal K., Yoshikura N.: An autopsy case of progressive supranuclear palsy with Lafora-like intraneuronal inclusions. Adv. Neurol. Sci., 19, 384-395, 1975. (Abstract in English).

[94] Kurihara T., Landau W.M., TORack R.M.: Progressive supranuclear palsy with action myoclonus, seizures. Neurology (Minneap.), 24, 219-223, 1974.

[95] Laffont F., Autret A., Minz M., Beillevaire T., Gilbert A., Cathala H.P., Castaigne P.: Etude polygraphique du sommeil dans 9 cas de maladie de Steele-Richardson. Rev. Neurol. (Paris), 135, 127-142, 1979.

[96] LAURENT B.: Syndrome de Steele-Richardson et Olszewski. Données oculographiques et polygraphiques; test au probénécide. A propos de 10 observations dont 3 anatomo-cliniques. Thèse, Lyon, 1976.

[97] LEY R.A.: Forme atypique d'atrophie cérébelleuse ayant évolué en syndrome rigide. J. Neurol. Psychiatrie, 25, 92-108, 1925.

[98] Leygonie F., Thomas J., Degos J.D., BouchaREINE A., BARBIZET J.: Troubles du sommeil dans la maladie de Steele-Richardson. Etude polygraphique de 3 cas. Rev. Neurol. (Paris), $132,125-136,1976$.

[99] Liaño H., Gimeno A.: Síndrome de Steele Richardson-Olszewski. Estudio clínico-radiologico de un caso. Rev. Neurol. (Barcelona), 2, 257-264, 1974.

[100] ManNen T., TOYOKURA Y., TSUKagoshi H., MiYatake T., Mohri N., Yokoyama T.: Progressive supranuclear palsy: Report of autopsied case. Adv. Neurol. Sci., 16, 497-503, 1972. (In Japanese).

[101] Mano Y., Watanabe H., Nagata Y., NishIGAKI S.: An autopsied case of progressive supranuclear palsy. Clin. Neurol. (Tokyo), 14, 399-405, 1974. (Abstract in English).

[102] Mastagla F.l., Grainger K., Kee F., Sadka M., LEFROY R.: Progressive supranuclear palsy (The Steele-Richardson-Olszewski syndrome). Clinical and electrophysiological observations in eleven cases. Proc. Aust. Ass. Neurol., 10, $35-44,1973$.

[103] Mastagla F.L., Grainger K.M.R.: Internuclear ophtalmoplegia in progressive supranuclear palsy. J. Neurol. Sci., 25, 303-308, 1975.

[104] Masters C.L., Harris J.O., Gajduser D.C., GIBBS C.J., jr., BERNOULlI C., ASHER D.M.: Creutzfeldt-Jakob disease: Patterns of worldwide occurrence and the significance of familial 
and sporadic clustering. Ann. Neurol., 5, 177-188, 1979.

[105] Mendell J.R., Chase T.N., Engel W.K.: Modification by L-Dopa of a case of progressive supranuclear palsy with evidence of defective cerebral dopamine metabolism. Lancet, $\mathrm{i}$, 593-594, 1970.

[106] Messert B., Van Nuis C.: $A$ syndrome of paralysis of downward gaze, dysarthria, pseudobulbar palsy, axial rigidity of neck and trunk and dementia. J. Nerv. Ment. Dis., 143, 47-54, 1966.

[107] Michel D., Tommasi M., LauRent B., TRILlEt M., Schoтt B.: Dégénérescence striato-nigrique. $A$ propos de deux observations anatomocliniques. Rev. Neurol. (Paris), 132, 3-22, 1976.

[108] Miquel F., Codina A., Montserrat L.: Parálisis supranuclear progresiva. Estúdio electromiográfico $y$ electronistagmográfico. XXXV Reunión Anual Soc. Esp. Neurol., Barcelona, 1973.

[109] Mironi F., Vitiello L., Violante A.: "Viscosità" dei movimenti oculari, con evoluzione pseudoftalmoplegica, associata a rigidità distonica, amiotrofia neurogena e segni piramidali. Riv. Otoneurooftalmol., 44, 291-308, 1969.

[110] Mones R.J.: An analysis of six patients with Parkinson's disease who have been unresponsive to L-dopa therapy. J. Neurol. Neurosurg. Psychiatry, 36, 362-367, 1973.

[111] Morariv M.A.: Progressive supranuclear palsy and normal-pressure hydrocephalus. Neurology (Minneap.), 29, 1544-1546, 1979.

[112] Morax P.V., Aron-Rosa D., de Bartholo I., Contamin F., Mignot M.: Les paralysies supranucléaires progressives. La dystonie oculo-faciocervicale de Steele, Richardson et Olszewski ià propos de 7 nouvelles observations). Ann. Oculist. (Paris), 207, 267-278, 1974.

[113] MrożeK K., KamtísKa A., Marciniak M.: Przypadek porazenia nadjadrowego postepujacegoz zazjecciem rogów przednich rdzenia [A case of progressive supranuclear palsy with involvement of spinal anterior horns]. Neur. Neurochir. Pol., 22, 631-635, 1972.

[114] Mroźex K., KamińsKa A., MarciniaK M.: Próba stosowania larodopy $i$ viregytu $w$ przypadku porazenia nadjadrowego postępujacego [A trial of larodopa and viregyt treatment in a case of progressive supranuclear palsy]. Wiad. Lek., 25, 1019-1023, 1972.

[115] Nagamatsu K., Shida K., Kuroiwa Y.: A case of apraxia of lid opening, dementia, pseudobulbar palsy, nuchal rigidity, hyperreflexia and unsteadiness. Clin. Neurol. (Tokyo), 12, 111-115, 1972. (Abstract in English).

[116] Nagashima T., Yamada K., Uono M., Nagashima K., Matsuyama H.: Chronic encephalitis showing progressive supranuclear palsy syndrome. Clinicopathological, viral and immunological studies of a rare autopsy case. Adv. Neurol. Sci., 21, 538-547, 1977. (Abstract in English).

[117] NeUMANN M.A.: Combined degeneration of globus pallidus and dentate nucleus and their projections. Neurology (Minneap.), 9, 430-438, 1959.
[118] NeumanN M.A.: Further studies on pathologic changes in the reticular formtion. Proc. 4th Int. Cong. Neuropathol., München 1961. Stuttgart, G. Thieme, 1962, vol. 3, pp. 377-380.

[119] NeumanN M.A.: Heterogenous system degenerations with particular involvement of the reticular substance: Correlation with neurologic disorders and the concept of Creutzfeld-Jakob disease. J. Neuropathol. Exp. Neurol., 20, 316-319, 1961

[120] Neumann M.A.: Pathology of the reticular formation, in J. Minckler, ed., Pathology of the Nervous System. New York, McGraw-Hill, 1968, vol. 1, pp. 696-707.

[121] Neumann M.A.: Pontocerebellar atrophy combined with vestibular-reticular degeneration. Mt. Sinai J. Med., 36, 321-337, 1977.

[122] Newman N., Gay A.J., Stroud M.H., Brooks J.: Defective rapid eye movements in progressive supranuclear palsy. An ocular electromyographic study. Brain, 93, 775-784, 1970.

[123] Nyberg-Hansen R., Holmsen R.: Progressiv supranukleaer parese. Tidsskr. Nor. Laegeforen., 98, 430-434, 1978.

[124] OLszEwski J.: Heterogeneous system degeneration. Progressive supranuclear palsy - Ocular, facial and bulbar. 2nd Symposium on Parkinson's Disease. J. Neurosurg., 24, suppl., 250-254, 1966.

[125] Olszewski J., Steele J., Richardson J.C.: Pathological report on six cases of heterogeneous system degeneration. Am. Ass. Neuropathol. 39th Ann. Meet., Atlantic City, 1963. J. Neuropathol. Exp. Neurol., 23, 187-188, 1964.

[126] Perkin G.D., Lees A.J., Stern G.M., Kocen R.S.: Problems in the diagnosis of progressive supranuclear palsy (Steele-Richardson-Olszewski syndrome). Can. J. Neurol. Sci., 5, 167-173, 1978.

[127] Pfaffenbach D.D., Layton D.D. jr., Kearns Tн.P.: Ocular manifestations in progressive supranuclear palsy. Am. J. Ophthalmol., 74, 1179-1184, 1972.

[128] PiCARD E.H., Richardson E.P., jr.: Case records of the Massachusetts General Hospital. Case 32-1975. N. Engl. J. Med., 293, 346-352, 1975.

[129] Pinhas I., Pinhas A., Goldhammer Y., BRAHAM J.: Progressive supranuclear paisy: Electromyographic examinations of eye muscles. Acta Neurol. Scand., 58, 304-308, 1978.

[130] Pollingher B.: Sindromul Steele-RichardsonOlszewski. Neurologia (Bucur.), 13, 413-418, 1968.

[131] PosEY W.C.: Paralysis of the upward movements of the eyes. Ann. Ophthalmol., 13, 523-529, 1904.

[132] Powell D.: Progressive supranuclear palsy. J. Irish Med. Assoc., 63, 189-190, 1970.

[133] Powell H.C., LoNdon G.W., LAMPERT P.W.: Neurofibrillary tangles in progressive supranuclear palsy. Electron microscopic obsevations. J. Neuropathol. Exp. Neurol., 33, 98-106, 1974.

[134] Prosst A.: Dégénérescence neurofibrillaire sous-corticale sénile avec présence de tubules contournés et de filaments droits. Forme atypique de la paralysie supranucléaire progressive. 
Rev. Neurol. (Paris), 133, 417-428, 1977.

[135] Probst A., Dufresne J.J.: Paralysie supranucléaire progressive lou dystonie oculo-faciocervicale). Etude clinique et neuropathologique. Arch. Suisses Neurol. Neurochir. Psychiatrie, 116, 107-134, 1975.

[136] Rafal R.D., Gummow L., GRMM R.J.: Treatment of progressive supranuclear palsy with methysergide: Neuropsychologic improvement in five patients. Neurology (Minneap.), 27, 351, 1977.

[137] RAFAL R.D., GRIMM R.J.: Management of progressive supranuclear palsy. Personal communication, 1977.

[138] Rajput A.H., Chorneli G., Rozdisky B.: Progressive external ophthalmoplegia with parkinsonism and dementia. Treatment with L-dopa. Can. J. Ophthalmol., 7, 368-374, 1972.

[139] RebeIz J.J., KolodNY E.H., RICHARDSON E.P., jr.: Corticodentatonigral degeneration with neuronal achromasia. Arch. Neurol., 18, 20-33, 1968.

[140] Renaud B., Mouret J., Chazot G., Michel D., LAUReNT B., Quincy C.: Exploration pharmacologique du métabolisme des monoamines cérébrales par le test au probénécide: interêt et limites. Les neuromédiateurs du tronc cérébral. 2ème Réunion Int. Hôp. Neurol., Lyon, 1979. Paris, Sandoz Ed., pp. 23-24.

[141] Richardson C.: Progressive supranuclear palsy - Ocular, facial, and bulbar. 2nd Symposium on Parkinson's Disease. J. Neurosurg., 24, suppl., 281-283, 1966.

[142] Richardson J.C., Steele J., Olszewski J.: Supranuclear ophthalmoplegia, pseudobulbar paisy, nuchal dystonia and dementia. A clinical report on eight cases of heterogeneous system degeneration. Trans. Am. Neurol. Assoc., 88, 25-29, 1963.

[143] Rizzo A.: Paralisia supranuclear progressiva: aspectos pneumencefalográficos. Arq. Neuropsiquiatr., 32, 314-318, 1974.

[144] Rizzuto N., Vio M.: Sur un syridrome de dystonie oculo-facio-cervicale se traduisant par une dégénérescence plurisystematisée du SNC avec état pigmentaire pallidoréticulé. Acta Neurol. Belg., 69, 1026-1037, 1969.

[145] Rosemblum W.I., Hooshmand H., HaRbison J.: Meningoencephalitis as a cause of fulminant disease with features of progressive supranuclear palsy. J. Neuropathol. Exp. Neurol., 31, 174, 1972.

[146] Rouzaud M., Degiovanni E., Jobard P., GRAY F., DURAND J.P.: L'ophtalmoplégie supranucléaire progressive (syndrome de Steele. Richardson-Olszewski). Nouvelle observation anatomo-clinique. Rev. Neurol. (Paris), 130, 143-164, 1974.

[147] Rouzaud M., Degiovanni E., Gray F., RossAZZA C., DURAND J.P.: Les manifestations oculaires du syndrome de Steele-RichardsonOlszewski (à propos de 2 observations). Rev. Otoneuroophtalmol., 47, 307-315, 1975.

[148] Roy S., DatTa C.K., Hirano A., Ghatak N.R., ZmMmerMaN H.M.: Electron microscopic study of neurofibrillary tangles in SteeleRichardson-Olszewski syndrome. Acta Neuropa- thol. (Berl.), 29, 175-179, 1974.

[149] SAcks O.W.: L-dopa for progressive supranuclear palsy. Lancet, ii, 591-592, 1969.

[150] Samaras G.: Progressive supranuclear palsy (Dystonie oculo-facio-cervicale). Thesis, Salonica, 1970. (Abstract in English).

[151] SANDERS M.D., BIRD A.C.: Supranuclear abnormalities of the vertical ocular motor system. Trans. Ophthaimol. Soc. U.K., 90. 433-450, 1970.

[152] SCHAinKer B.A.: Autopsy diagnosis of progressive supranuclear palsy mistaken clinically for stroke. Case report. Mo. Med., 75, 227-229, 1978.

[153] Schleider M.A., Nagurney J.T.: Progressive supranuclear ophthalmoplegia. Association with cricopharyngeal disfunction and recurrent pneumonia. JAMA, 237, 994-995, 1977.

[154] SChotT B., Michel D., Mouret J., Renaud B., Quenin P., Tommasi M.: Monoamines et régulation de la vigilance. II. Syndromes lésionnels du système nerveux central, Rev. Neurol. (Paris), 127, 157-171, 1972.

[155] Scotr D.: Progressive supranuclear palsy in a Navajo. Rocky Mt. Med. J., 67, 35-37, 1970.

[156] Seitelberger F.: Heterogeneous system degeneration. Subcortical argyrophilic dystrophy. Acta Neurol. (Napoli), 24, 276-284, 1969.

[157] SHibasaki H., TsujI S., Kurolwa Y.: Oculomotor abnormalities in Parkinson's disease. Arch. Neurol., 36, 360-364, 1979.

[158] Simonetti C., Ferrarini F.: La paralisi souranucleare progressiva (Rassegna della letteratura $e$ contributo casistico). Neopsichiatria, 38, $631.660,1972$.

[159] Singh N., Vijayan G., Narayanan $S$.: Progressive supranuclear palsy (Steele-Richardson-Olszewski-syndrome) (Report of three cases and review of the literature). J. Assoc. Physicians India, 24, 251-256, 1976.

[160] Singh S., Smith B.H., Lal A.: Progressive supranuclear palsy (Report of 4 cases with particular reference to blepharospasm and levodopa therapy). Neurol. India, 22, 65-71, 1974.

[161] SMITH J.L.: Ocular signs of Parkinsonism. 2nd Symposium on Parkinson's Disease. J. Neurosurg., 24, suppl., 284-285, 1966.

[162] SPLLER W.G.: The importance in clinical diag. nosis of paralysis of associated movements of the eyeballs (Blicklaehmung), especially of upward and downward associated movements. J. Nerv. Ment. Dis., 32, $417-448$ and 497-530, 1905.

[163] SPISSU A., ORZALESI N.: I disturbi della motilità oculare nella sindrome di Steele-RichardsonOlszewski. Riv. Neurol., 44, 253-259, 1974.

[164] Stadlan E.M., Duvoisin R., YaHR M.: The pathology of Parkinsonism. Proc. 5th Int. Cong. Neuropathol., Zurich, 1965. Int. Cong. Series, Amsterdarn, Excerpta Med. Found,, 100, $569.571,1965$.

[165] STEELE J.C.: Progressive supranuclear palsy. Report of a Thai patient. J. Med. Assoc. Thai., 53, 364-368, 1970.

[166] Steele J.C.: Progressive supranuclear palsy. Brain, 95, 693-704, 1972.

[167] Steele J.C.: Progressive supranuclear palsy, in 
P.J. VINKEN, S.W.BRUYN, (eds.), Handbook of Clinical Neurology. Amsterdam, North Holland Publ. Co., New York, American Elsevier Co., 1975, vol. 22, pp. 217-229.

[168] Steele J.C., Richardson J.C., Olszewski J.: Progressive supranuclear palsy. A heterogeneous degeneration involving the brain stem, basal ganglia and cerebellum with vertical gaze and pseudobulbar palsy, nuchal dystonia and dementia. Arch. Neurol., 10, 333-359, 1964.

[169] STdIER M.: Paresis supranuclearis progressiva. Et nyt sygdomsbillede? Nord. Med., 73, 362-364, 1965.

[170] Su Ph. C., Goldensohn E.S.: Progressive supranuclear palsy. Elctroencephalographic studies. Arch. Neurol., 29, 183-186, 1973.

[171] SzUlC-KubERSKA J.: Dystonia oczno-twarzowoszyjna (zespól Steele'a-Richardsona-Olszewskiego) [Ophthalmo-facial-cervical dystony (The syndrome of Steele-Richardson-Olszewski)]. Neurol. Neurochir. Pol., 1, 401-404, 1967.

[172] Tashiro K., Hamada T., IWASaki Y., TSURU M., ABe S., Warabi T., Kase M.: Progressive supranuclear palsy: Report of two cases, with special reference to its clinical manifestations and pneumoencephalo-tomographic findings. Brain Nerv., 29, 561-567, 1977. (Abstract in English).

[173] Tellez-NAGEL I., WiŚNIEWSKI H.M.: Ultrastructure of neurofibrillary tangles in SteeleRichardson-Olszewski syndrome. Arch. Neurol., 29, 324-327, 1973.

[174] TÖвEL FR.: Klinischer und anatomischer Beitrag zur Entstehung der extrapyramidalen Symptome bei cerebellären Erkrankungen. Arch. Psychiatr. Z. Neurol., 188, 328-338, 1952.

[175] TolosA E.S., ZEESE J.A.: Brainstem auditory evoked responses in progressive supranuclear palsy. Ann. Neurol., 6, 369, 1979.

[176] Tomonaga M.: Ultrastructure of neurofibrillary tangles in progressive supranuclear palsy. Acta Neuropathol. (Berl.), 37, 177-181, 1977.

[177] TORVIK A., MEEN D.: Distribution of the brain stem lesions in post-encephalitic Parkinsonism. Acta Neurol. Scand., 42, 415-425, 1966.

[178] Trávíx K.: Pripad okulofaciocervikálnej dystónie (Progressive supranuclear palsy) [A case of oculo-facio-cervical distonia (Progressive supranuclear palsy)]. Čsk. Neurol. Neurochir., 37/70, 191-195, 1974.

[179] Trevisan C., Testa G.F., Angelini C.: Paralisi sopranucleare progressiva. Considerazioni su due casi. Riv. Pat. Nerv. Ment., 96, 159-165, 1975.

[180] TRIDON P., Weber M.: Essais de la L-dopa dans un gas de syndrome de Hunt et de Steele-Richardson-Olszewski. Colloqui Larodopa Roches Paris, 83-84, 1970.
[181] Troost B.T., DARoff R.B.: The ocular motor defects in progressive supranuclear palsy. Ann. Neurol., 2, 397-403, 1977.

[182] UMEDA E.: Progressive supranuclear palsy. Consideration from neurotological point of view. Clin. Neurol. (Tokyo), 17, 746-750, 1977. (Abstract in English).

[183] UMEDA Y., SAKata E.: A case of progressive supranuclear palsy: Neurotological findings and etioloy. J. Otolaryngol., 7, 409-414, 1978.

[184] Van BogaerT L., Bertrand I.: Une variété d'atrophie olivo-pontine à évolution subaigüe avec troubles démentiels. Rev. Neurol. (Paris), $1,165-178,1929$.

[185] V ARELA J.M.: Atrophies de la formation réticulaire du névraxe. I. Atrophie systématisée réticulaire globale. Syndrome de dyshoméostasie du névraxe. 2ème partie. Psychiatr. Clin. (Basel), 2, 109-123, 1969.

[186] VARELA L., FERRER S.: Paralisis supranuclear progresiva. Progressive supranuclear paralysis. Neurocirugia, 33, 154-159, 1975.

[187] Velmurugendran C.U., ARJundas G., JaganNATHAN K.: Progressive supranuclear palsy. Proc. Inst. Neurol. Madras. 5, 120-128, 1975.

[188] VERHAART W.J.C.: An unclassified degenerative disease of the central nervous system. Arch. Neurol. Psychiat., 44, 1262-1270, 1940.

[189] VeRHAART W.J.C.: Degeneration of the brain stem reticular formation, other parts of the brain stem and the cerebellum. An example of heterogenous systemic degeneration of the central nervous system. J. Neuropathol. Exp. Neurol., 17, 382-391, 1958.

[190] Wada S., Goya T., Matsukado Y.: Progressive supranuclear palsy after head injury. Case report. Clin. Neurol. (Tokyo), 16, 496-502, 1976. (Abstract in English).

[191] WAgshull A., DarofF R.B.: L-dopa for progressive supranuclear palsy. Lancet, ii, 105-106, 1969.

[192] Wagshull A., DarofF R.B.: Depression during L-dopa treatment. Lancet, ii, 592, 1969.

[193] Walsh F.B., Hoyt F.W.: Clinical NeuroOphthalmology, 3rd ed. Vol. 1. Baltimore, Williams \& Wilkins, 1969, pp. 1013-1014.

[194] WeINMANN R.L.: Heterogeneous system degeneration of the central nervous system associated with peripheral neuropathy. Neurology (Minneap.), 17, 597-603, 1967.

[195] WEINMANN R.L.: Heterogeneous system degeneration and progressive supranuclear palsy: Electroencephalographic changes. Clin. Electroencephalography, 5, 31-33, 1974.

[196] Yagishita S., ItoH Y., AMano N., Nakano T., SarroH A.: Ultrastructure of neurofibrillary tangles in progressive supranuclear palsy. Acta Neuropathol. (Berl.), 48, 27-30, 1979. 